\title{
Ifigênia e o Campo de Visão: poesia visionária
}

\author{
Michelle GONÇALVES ${ }^{1}$ \\ Marcelo LAZZARATTO ${ }^{2}$ \\ Universidade Estadual de Campinas - Unicamp
}

O espetáculo Ifigênia da Cia. Elevador de Teatro Panorâmico - dirigido por Marcelo Lazzaratto e escrito por Cássio Pires, a partir de Ifigênia em Aulis, de Eurípides - é uma espécie de coroação do processo de pesquisa e desenvolvimento do "Campo de Visão" técnica-poética (LAZZARATTO, 2011, p. 92) ${ }^{3}$ que se presta tanto ao treinamento do ator quanto à construção da cena - investigado há vinte anos por Lazzaratto e há doze sistematizado com os atores da Cia., é objeto da pesquisa de mestrado que realizo desde agosto de 2012 no Instituto de Artes da Unicamp ${ }^{4}$.

O Campo de Visão é fundamentado na improvisação e Ifigênia é, por consequência, um espetáculo improvisacional. Mas antes de entrarmos em seus pormenores, é importante ressaltar que tanto no Campo de Visão como em Ifigênia a palavra "improvisação" tem um sentido muito diferente do que é atribuído, frequentemente, pelo senso comum, no qual ela costuma ser entendida pejorativamente como algo descuidado, sem a devida preparação, mal feito. Aqui, a improvisação é entendida como uma matéria ligada à capacidade do ator de se entender como um jogador (por sinal, em outras línguas, a palavra que diz respeito à atividade do ator - que de certa forma corresponde ao nosso "atuar" - é "jogar", em inglês, to play e em francês, jouer), à capacidade de estar absolutamente presente no acontecimento e responder criativamente ao que acontece no agora, à espontaneidade, ao frescor, à

\footnotetext{
${ }^{1}$ Mestranda em Artes da Cena pela Unicamp, orientanda de Marcelo Lazzaratto. Formada em Licenciatura em Artes Cênicas pela UFMG e no Curso Técnico Profissionalizante do Centro de Formação Artística da Fundação Clóvis Salgado - Palácio das Artes (BH), é integrante do Coletivo Teatral Filme Bê e Programadora Cultural da Oficina Cultural Oswald de Andrade. E-mail: michacostag@yahoo.com.br.

2 Ator, diretor, pesquisador teatral e Doutor em Artes. Leciona no Depto. de Artes Cênicas da Unicamp e é diretor artístico da Cia. Elevador de Teatro Panorâmico. Publicou em 2011 o livro "Campo de visão: exercício e linguagem cênica". E-mail: marevi@uol.com.br.

${ }^{3}$ O Campo de Visão é um treinamento que não se esgota na aquisição de competências, mas produz sentido e poesia, mesmo quando não está a serviço de uma encenação.

4 Antes de me debruçar sobre esta reflexão sobre o espetáculo, esclareço que o olhar aqui lançado sobre o trabalho está amparado em algumas condições: ao assistir ao espetáculo, eu já possuía conhecimento prévio sobre os procedimentos fundamentais do Campo de Visão, no entanto, estou em pleno processo de investigação de seus pormenores; durante o processo de criação da peça, pude acompanhar, parcialmente, através de relatos de artistas envolvidos, alguns dos procedimentos utilizados em sua construção, mas apenas depois de assisti-la algumas vezes foi que tive acesso a detalhes importantes de seu processo de criação. Tendo isto em vista, é importante ressaltar que me permito fazer esta reflexão sobre a peça tentando articular o ponto de vista da pesquisadora, de quem a conhece para além da experiência compartilhada com a maior parte de seus espectadores, mas, em certa medida, tentando preservar também as impressões do impacto que senti ao assisti-la, ou seja, do ponto de vista da espectadora.
} 
capacidade de ser mais que um ator, mas de se tornar autor e, ainda mais, de se fazer verdadeiramente um artista, um criador. Deste ponto de vista, a capacidade de improvisar é, portanto, uma habilidade bastante desejável ao ator, mas é, também, algo que exige preparo, técnica, treinamento, algo que precisa ser desenvolvido durante seu perpétuo estado de formação.

Por se tratar de um fenômeno intrínseco ao fazer teatral, que teve diferentes escalas de importância e impacto ao longo da história, a improvisação tem sido matéria de estudo de diversos pesquisadores ao longo do tempo. Michel Corvin (1998), em seu Dictionaire encyclopédique du théâtre, faz uma divisão em três grandes categorias de aplicação no teatro contemporâneo: improvisação como instrumento de construção de um espetáculo, improvisação na formação do ator e improvisação como espetáculo. Todas elas são aplicáveis ao Campo de Visão e ao Ifigênia.

A fim de possibilitar uma melhor compreensão do que se trata a experiência teatral de Ifigênia, abaixo descrevo brevemente o que é o Campo de Visão.

\section{O Campo de Visão}

Marcelo Lazzaratto conheceu o exercício Campo de Visão através de Marcio Aurélio, diretor da Cia. Razões Inversas, onde trabalhou como ator de 1991 a 2000. Ele afirma que desconhece sua fonte criadora, mas desconfia que possa ser uma variável do exercício "Siga o Mestre", de Viola Spolin, ou dos "Círculos de Atenção", de Stanislavski.

A identificação de Lazzaratto com este exercício improvisacional fez com que, durante alguns anos, ele se debruçasse sobre a investigação de suas possibilidades em sala de aula com seus alunos. No entanto, o fato de estar inserido em instituições com diretrizes didático-pedagógicas próprias o impedia de se aprofundar na pesquisa da maneira como gostaria.

Em 2000, com a criação da Cia. Elevador de Teatro Panorâmico, da qual é diretor artístico, Lazzaratto pôde, enfim, desenvolver o Campo de Visão com profundidade. De lá pra cá, este sistema improvisacional vem sendo utilizado no processo de criação dos espetáculos da Cia. Elevador, não só como processo de treinamento do ator e ferramenta de disponibilização de material criativo para composição de personagens e criação de cenas, mas também como linguagem na construção poética dos espetáculos.

O Campo de Visão é regido por uma regra única, simples e abrangente: “Trata-se de um exercício de improvisação teatral coral no qual os participantes só podem 
movimentar-se quando algum movimento gerado por qualquer ator estiver ou entrar em seu campo de visão" (LAZZARATTO, 2011, p. 41).

Para elucidar o procedimento essencial do jogo, segue abaixo uma breve descrição de sua estrutura inicial de desenvolvimento, que chamarei de exercício base:

- É preciso que haja um condutor. Alguém que conheça bem as regras e que, observando de fora, ditará a dinâmica do exercício, com diferentes comandos durante o jogo. É importante que ele se coloque também como um jogador atento e sensível.

- O exercício começa quando o condutor dá o comando para que os atores se coloquem em 'Ponto Zero'. Isto significa que eles devem se posicionar promovendo a formação rigorosa de um U equilibrado no espaço. Nesta posição os atores devem estar neutros, mas em estado de alerta. Neste momento, os atores são motivados por um estímulo musical.

- Em seguida, o condutor dá o comando 'Entra'. Os atores devem, então, responder fazendo o primeiro movimento que lhes acontecer e sustentar a posição até ouvirem o comando 'Desenvolve', quando devem desenvolver uma movimentação que se dê a partir da resposta dada ao primeiro estímulo e em diálogo com a música.

- Depois de um tempo de desenvolvimento individual de cada participante, o condutor chama o nome de um dos atores na sequência da expressão 'Campo de Visão' (por exemplo, “Campo de Visão, João") e aí começa de fato a valer a regra única do Campo de Visão: o ator chamado passa a ser o líder e todos os outros atores devem suspender o movimento que estavam fazendo individualmente e seguir o líder se ele estiver - ou quando ele ou outro jogador que já o esteja seguindo entrar - em seu campo de visão. Os seguidores devem tentar reproduzir o movimento do líder com o máximo de rigor, obedecendo, necessariamente, sua direção e sentido. Isso significa que eles nunca se olharão nos olhos, o que leva os jogadores a ampliar sua visão periférica, sua percepção do espaço e sua capacidade de estabelecer relação com o outro, jogando em cena sem a contracenação frontal a que a maior parte dos atores está acostumada. Se durante a movimentação o líder ou qualquer um dos seguidores ficar sem nenhum outro jogador em seu campo de visão, ele deve suspender a ação mantendo-se em alerta até que algum movimento entre novamente em seu campo visual.

- Em qualquer momento o condutor pode chamar o nome de outro ator, que passa automaticamente a ser o líder. Então ele será seguido pelos outros jogadores quando algum movimento seu entrar no campo de visão deles. Os demais jogadores devem, novamente, 
tentar apropriar-se ao máximo dos detalhes e da intencionalidade do movimento do líder. Depois um novo ator será chamado a liderar e assim por diante.

- Quando desejar finalizar o exercício, o condutor dá novamente o comando 'Ponto Zero' e os atores retornam, imediatamente, às suas posições iniciais. Em 'Ponto Zero', os jogadores devem fazer a recuperação silenciosa dos acontecimentos que tiverem sido mais significativos para cada um.

O Exercício Base é a estrutura essencial do Campo de Visão, mas, na apropriação de Lazzaratto, muitos elementos são introduzidos e diversas variações surgem a partir daí. É no desenvolvimento destas possibilidades que consiste sua investigação com a Cia. Elevador de Teatro Panorâmico e é o que faz o Campo de Visão passar de simplesmente um jogo teatral interessante a uma potente ferramenta de treinamento do ator, de construção poética da cena e de desenvolvimento de linguagem espetacular.

A descrição detalhada de cada um destes elementos e variações não é matéria para este trabalho. No entanto, descrevo abaixo, superficialmente, algumas das etapas do desenvolvimento desta pesquisa que permitiu que a Cia. Elevador alcançasse uma qualidade de jogo entre os atores fundamental para que o Campo de Visão pudesse transformar-se em linguagem cênica, culminando com a construção de Ifigênia.

Se no exercício base o estímulo é apenas a música - e ela seguirá presente, em maior ou menor medida, em outros estágios -, em uma fase posterior, quando o grupo de jogadores já exercitou por um tempo o Campo de Visão, são introduzidos pouco a pouco, elementos como:

- a relação espacial: o líder deve desenvolver sua movimentação, com o foco no fato de que suas escolhas definem a ocupação que será feita do espaço. Ele torna-se compositor da cena (se, por exemplo, ele faz um movimento que o tira do campo de visão de parte dos jogadores, estes ficarão parados e o desenvolvimento que ele propuser com o restante do grupo em movimento gerará leituras possíveis advindas desta imagem).

- a 'Imagem Estruturante': o ator deve conceber, enquanto está no Ponto Zero, algo real e concreto de grandes proporções (como por exemplo, um estádio, um navio, um trem) para construir no espaço quando assumir a liderança, trazendo à tona, novamente, a perspectiva de que seu movimento é uma ferramenta de composição da cena;

- o objeto: cada ator traz para o trabalho um objeto, que a princípio é trabalhado de forma imaginaria e posteriormente com o objeto em si. Entende-se em jogo, entre outras coisas, que possibilidades do movimento com determinado objeto são descobertas ao 
seguir alguém que é motivado e conduzido por um objeto absolutamente diferente do seu e que novos sentidos seu objeto e sua movimentação podem ter.

- os temas: definidos pelo líder no Ponto Zero, devem ser abstratos nas primeiras experiências. À medida que o processo avança temas cotidianos são propostos, buscando sempre a amplificação de seus sentidos, evitando ilustrações e buscando no corpo movimentos que sintetizem o tema e deem vida à imagem gerada por ele.

- a voz: a princípio aparece como som e não como palavra, surgindo como resposta ao movimento ou como estímulo a ele. Os sons podem ser reproduzidos pelos demais quando alguém se torna líder e vocaliza, tornando-se um poderoso estímulo energético e de conexão entre os jogadores.

- a palavra: aparece em estágio mais avançado e cada ator escolhe um pequeno texto que seja significativo para si. $\mathrm{O}$ ator deve trabalhar o texto para além do significado, explorando as possibilidades da palavra em si (sonoridade, ritmo, intensidade, etc.). $\mathrm{O}$ coletivo pode seguir a movimentação de um líder que diz seu próprio texto ou seguir um líder que se movimenta em silêncio enquanto um outro pronuncia o texto - este último é um jogo muito potente, pois se alteram as possibilidades motivacionais: o texto de outro estimula o movimento do líder e/ou o líder transforma a forma de dizer o texto de alguém.

- o personagem: a partir, por exemplo, de uma peça em que o grupo está trabalhando, existem muitas possibilidades de investigação. Todos os atores podem entrar no jogo com o mesmo personagem, cada um pode trabalhar com o seu, podem, ainda, entrar movidos pelo imaginário da peça e deixar que os personagens surjam a partir do jogo, etc. Esta é uma ferramenta poderosa para que todos os atores compreendam melhor o seu e os demais personagens da peça e para que ampliem seu repertório gestual e corporal, descobrindo possibilidades para a composição de seu personagem que não apareceriam se estivessem em trabalho solitário.

- a existência de mais de um líder: enquanto um ator lidera, o condutor chama um segundo líder deixando claro que o primeiro não deve suspender seus movimentos, formando-se dois ou mais grupos (dependendo de quantos líderes forem nomeados), desenvolvendo-se e compondo no espaço.

Estas são apenas algumas das etapas/possibilidades de trabalho com o Campo de Visão, técnica que Marcelo Lazzaratto de fato sistematizou durante a montagem do espetáculo $A$ hora em que não sabiamos nada uns dos outros, de Peter Handke. Foi neste momento, depois de dois anos de experimentação com a Cia. Elevador, que ele chegou ao

\footnotetext{
${ }^{5}$ Para conhecer melhor o Campo de Visão, ver LAZZARATTO (2011).
} 
que, mais tarde, denominou "Campo de Visão Livre", procedimento que, dez anos depois, foi fundamental para construção do espetáculo Ifigênia: os atores entrariam no jogo e eles mesmos determinariam o líder quando quisessem, escolhendo livremente o momento em que o movimento do outro o alimentasse para começar a segui-lo, podendo entrar e sair livremente sem a interferência do condutor. Em seu livro, Lazzaratto (2011, p. 131) descreve assim o momento desta descoberta:

Em nenhum outro momento de professor ou diretor, ou até mesmo de ator, percebi o sentido profundo da improvisação como naquele dia. A liberdade oferecida aos atores aumentava e muito sua responsabilidade, sintonizava absolutamente todos os participantes, tornava o ator senhor de todas as suas escolhas e eram elas que determinariam sobremaneira os resultados adquiridos. Além de propiciar ao olhar estrangeiro, o olhar de fora, uma rica e original beleza plástica extraída do "novo" improviso. Essa nova plástica, constituída de partes e do todo, recolocaria o sentido primeiro do Campo de Visão ampliando-o, instaurando, na verdade, um Campo de Percepção. A esse procedimento dei o nome de Campo de Visão Livre, descoberta que propiciou a continuidade de minha investigação, abrindo a real possibilidade de alçar o Campo de Visão como linguagem cênica.

\section{O mar e suas ondas}

Em 2011 e 2012, com o auxílio do Programa Municipal de Fomento ao Teatro, da Secretaria Municipal de Cultura de São Paulo, a Cia. Elevador de Teatro Panorâmico esteve imersa em um projeto que articulava a investigação da Cia. sobre o Campo de Visão e o universo da tragédia, partindo do binômio coletivo-indivíduo e/ou coro-protagonista, elemento estruturante tanto do Campo de Visão quanto das tragédias. A principal ação deste projeto foi a montagem de um espetáculo. Inicialmente, sabiam que montariam uma tragédia cuja encenação fosse estruturada pelo Campo de Visão Livre. Ifigênia em Áulis, de Eurípides, foi escolhida por ser uma obra que abarcava fortemente a relação entre indivíduo e coletivo e os embates gerados pelas diferentes necessidades e desejos destas instâncias, matéria cara ao exercício do Campo de Visão e estruturadora de seus procedimentos.

O mar e suas ondas. Esta foi a imagem geradora do espetáculo, metáfora potente do binômio que articulava com precisão forma e conteúdo. No texto que o diretor escreveu para o programa da primeira temporada da peça, realizada no SESC Belenzinho em março de 2012 (p.2), lê-se: 
Para montagem de "Ifigênia" propus à equipe de criação - atores, dramaturgo, diretora de arte, compositor e iluminador - uma imagem como força motriz e guia de todo o trabalho: o Mar e suas Ondas.

O mar como metáfora do todo, do arquetípico, do coletivo.

A onda como metáfora da parte, da subjetividade, do indivíduo.

Imaginem que todos são mar (coletivo) e que de vez em quando uma onda se manifesta (indivíduo), desenha seus contornos específicos, dura seu tempo devido e depois se esvanece, reintegrando-se ao mar.

Mar ininterrupto, dinâmico, latente, gestador de tudo e de todos. Criador de suas ondas, que dele se manifestam sem deixar de o ser. As ondas nunca deixam de ser mar. Bem como os indivíduos, eles sempre pertencem a uma coletividade.

Forma: o Campo de Visão, um sistema improvisacional coral, em que o coro-mar é entendido não como uma massa estigmatizada, mas como a conexão das particularidades dos indivíduos-ondas que geram o coletivo. Assim como o Campo de Visão é regido por uma regra fundamental, podemos começar a entender Ifigênia a partir de uma regra básica: todos os atores sabem todo o texto de cor, mas não têm personagens fixos e tampouco movimentações definidas; a cada momento da apresentação estas escolhas são feitas pelos atores e o espetáculo constrói-se a partir da dinâmica do Campo de Visão Livre. Lazzaratto (2012, p. 2) descreve no programa:

Esse sistema chama-se "Campo de Visão". Ele é coletivo, coral. Ele é o nosso mar, ininterrupto, dinâmico, latente, gestador de tudo que se configurará na cena.

Utilizo-me do Futuro, "configurará", porque "Ifigênia" é um espetáculo em que os atores, os músicos e o operador de luz improvisam. Ou seja, a cada dia um novo espetáculo.

O "como" é que nunca será o mesmo. A cada dia as cenas se configurarão de maneira diferente, regidas pela dinâmica do "Campo de Visão". Dinâmica variável, movediça. Não há personagens definidos.

Não há, a priori, distinção entre coro e protagonistas. A cada dia, ou melhor, a cada momento do espetáculo, a "onda" Agamêmnon, gestada no mar "Campo de Visão", pode se manifestar em qualquer ator, por exemplo. Bem como a onda Clitemnestra ou Ifigênia. O mar improvisando suas ondas...

Conteúdo: o general Agamêmnon deverá oferecer sua filha com Clitemnestra, Ifigênia, ao sacrifício para que a caprichosa deusa Ártemis traga de volta o vento e, assim, os gregos possam navegar pelo mar Egeu até Troia e guerrear para vingar toda a Grécia que foi ultrajada quando Páris fugiu com Helena, esposa de seu irmão Menelau. Para muito além do determinismo do destino humano pela vontade dos deuses, a Cia. Elevador lançou um olhar sobre este mito que evidenciou um aspecto bem mais contundente, no que diz respeito às questões do nosso tempo: o embate entre as necessidades da coletividade (o mar) e os sentimentos e desejos individuais (as ondas). 


\section{A dramaturgia}

Ao identificar e eleger Ifigênia em Aulis, de Eurípides, conteúdo ideal para a forma que se delineava, Lazzaratto sabia que não se tratava de usar o texto grego em seu formato original e convidou o dramaturgo Cássio Pires para reescrever a obra. Propôs a ele que partisse da imagem mar-onda, da questão coletivo-indivíduo e que a história fosse contada do ponto de vista do coro.

Com uma escuta apurada e sensível das proposições de Lazzaratto, entendendo que as imagens motivadoras dadas a ele seriam também os norteadores dos procedimentos de criação da cena, e conhecendo (não profundamente) a estrutura fundamental do Campo de Visão - por já ter trabalhado com e assistido a Cia. Elevador em outros momentos ${ }^{6}-$ Cássio explode com a estrutura formal da tragédia e cria uma estrutura sob medida para o jogo idealizado por Marcelo. Ele, de fato, reescreve a peça, estabelecendo uma possibilidade potente de diálogo entre a dramaturgia e a construção da encenação - o Campo de Visão - recontando o mito em uma obra original, que em alguns momentos cita Eurípedes ${ }^{7}$. Além das radicais transformações estruturais, até mesmo os versos foram quase todos reescritos para que a métrica e a fluência servissem ao jogo que se estabeleceria. Pires diminuiu as rimas, mas preservou certa musicalidade, sem comprometer a força narrativa ${ }^{8}$.

A rubrica-poética inicial da peça - que aparece inclusive no início da encenação através de uma voz em Off - deixa claro o profundo entendimento estabelecido entre a proposta da direção e a criação da dramaturgia, sendo uma síntese precisa do que é o espetáculo Ifigênia (PIRES, 2012a, p. 47):

Tesoura e caneta sobre o original de Eurípedes.

O Porto de Áulis.

O herói arde em fogo, feito no atrito das pedras da ordenação do mundo e do desejo do individuo.

Texto fixo para cena improvisada.

Toda noite, eles contariam a mesma história sob o risco de uma nova encenação.

Poema para o verbo dever.

\footnotetext{
${ }^{6}$ Cássio Pires é autor da Peça de Elevador, que veio à cena em 2006, no Centro Cultural Banco do Brasil.

${ }^{7}$ Vale destacar o que o próprio Pires nos lembra no programa da peça sobre a autoria do original: "Ifigênia em Aulis é a última peça de Eurípides. Sua apresentação nas Dionisíacas de Atenas se deu pouco depois da morte de seu autor. Eurípides o jovem, figura entendida pelos helenistas como filho ou sobrinho do grande tragediógrafo, teria sido o responsável pela encenação da peça. Mas não só. Ele também teria finalizado o texto de seu ascendente, que o havia deixado inacabado.

Outra hipótese aventada diz que o final da peça, tal como o conhecemos hoje, teria sido escrito durante o período Bizantino, pelos eruditos responsáveis pela conservação das grandes tragédias produzidas no século V a. C., o século de Péricles.

Esse percurso de uma peça projetada e iniciada por um homem e completada por seus pósteros faz retomar o exercício de pensamento sobre a questão da autoria."

${ }^{8}$ Cássio Pires concedeu-me a entrevista sobre o processo de criação do texto em novembro de 2012. Todas as referências às opções e ao discurso do autor descritas neste texto são advindas dela.
} 
Uma onda é uma onda.

Ondas juntas são o mar

A divisão formal da tragédia é feita de episódios - passagens dialogadas dos personagens - e estásimos - comentários do coro no intervalo entre os episódios. Pires transforma os cinco episódios do original em oito cenas nomeadas Campo de Visão. Quem fala nestas cenas é o coro, o mar. Onde deveríamos ler o nome dos personagens, designando de quem é cada fala, lemos, em geral, ONDA/COREUTA, compondo o mar, narrador da história que, por vezes, deixa emergir uma de suas ondas, seus personagens, que aparecem em diálogos, onde leremos ONDA/IFIGÊNIA, ONDA/MENELAU, ONDA/CLIMTEMNESTRA, ONDA/AGAMÊMNON, ONDA/AQUILES, como podemos observar no trecho abaixo (PIRES, 2012a, pp. 53-4):

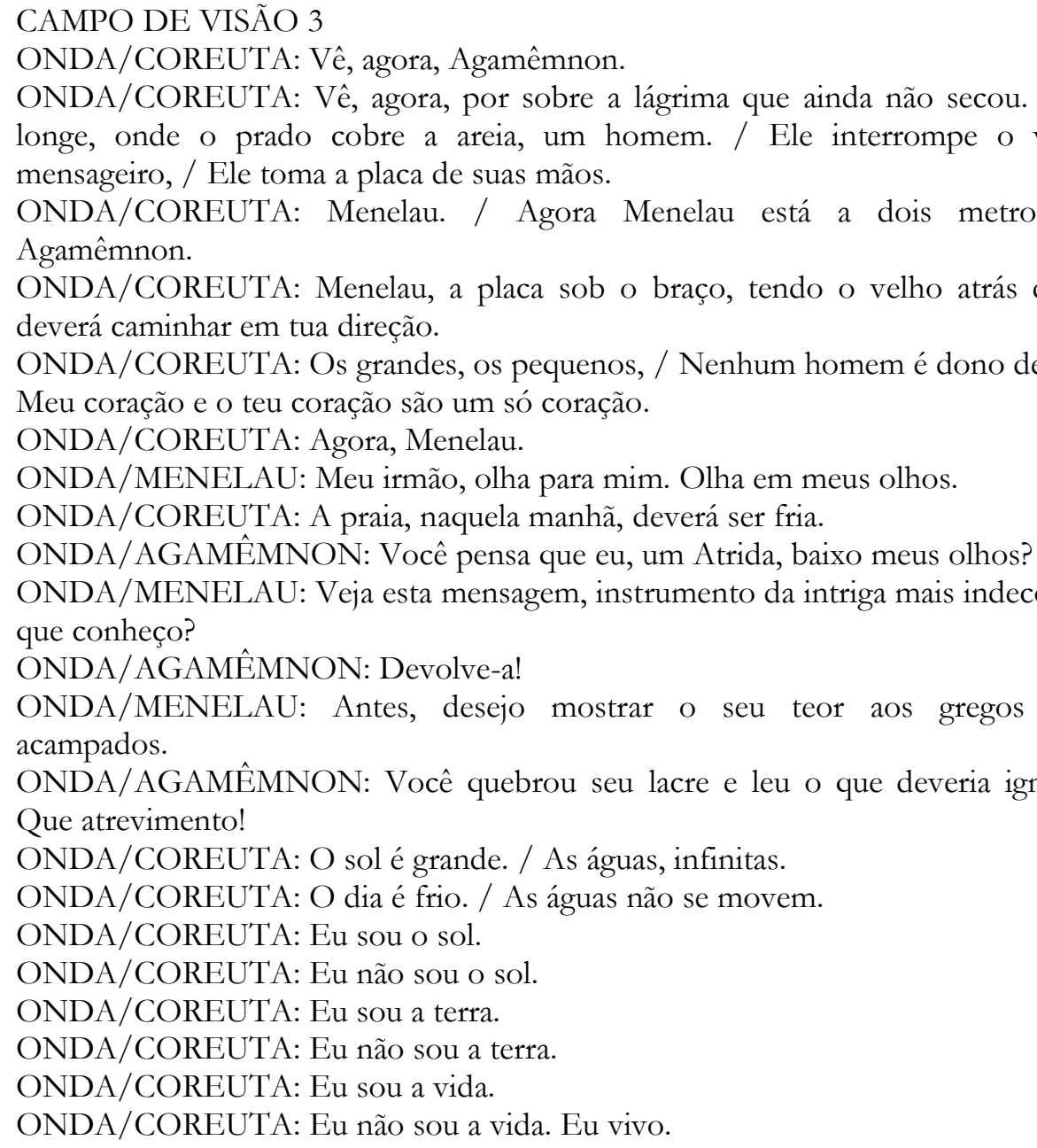

Os intervalos, as transições entre as cenas, são Ponto Zero e a voz que se houve aí, vinda das profundezas, é chamada MAR (aqui, não no sentido do coletivo e do macro, mas 
no sentido da profundidade) e, segundo o autor em entrevista, é um momento de pausa, tanto da ação da peça quanto da ação de Agamêmnon, em que emerge a voz do inconsciente de Agamêmnon a lhe falar. Abaixo seguem dois exemplos (Idem, pp. 48 e 51):

\author{
PONTO ZERO. \\ MAR. \\ A noite cai. \\ O dia nasce. \\ A luz é a mesma. \\ O mar também. \\ Ontem fui um. \\ Hoje sou outro. \\ PONTO ZERO. \\ MAR. \\ Na noite escura, \\ O menino chora. \\ $\mathrm{Na}$ noite escura, \\ $\mathrm{O}$ menino anseia. \\ Pela luz do dia, \\ Pela praia vazia, \\ Pelo verbo poder.
}

Para Cássio, o título mais adequado para esta peça seria Agamêmnon, pois é nele que reside o coração da contradição desta história, é ele o grande personagem trágico do mito. Em seu texto no programa da peça lemos "Ao opor a ordem familiar e a ordem do estado, a peça produz um de seus conflitos exatamente pela contradição de sentimentos entre o Agamêmnon pai e o Agamêmnon general” (PIRES, 2012b, p. 4).

E é deste ponto de vista que Pires a escreve: se no PONTO ZERO ouvimos a voz de seu inconsciente, é também para Agamêmnon que o Coro, a ONDA/COREUTA fala o tempo todo, neste caso é sua consciência a narrar pra si mesmo sua própria história, sua própria tragédia.

Há no texto um jogo de alternância entre os tempos verbais: o presente no PONTO ZERO - e em grande parte das vezes, na primeira pessoa do singular - e o futuro nas narrativas das ONDAS/COREUTAS - a maioria na terceira pessoa do singular, destacando-se, sobretudo, a presença incisiva do verbo deverá. A escolha por este jogo verbal é contundente e decisivo para que o leitor/espectador ouça a voz de Agamêmnon assistindo e narrando sua própria história, sentindo o peso do dever (verbo e substantivo) e prevendo as consequências que ele trará para sua vida.

Mas o que é fundamental na construção desta dramaturgia é a sua natureza desejante (TOSCANO, 2004). Ela não só deixa espaços para serem preenchidos pelos artistas na prática do palco, mas entende que esta é a proposta fundamental desta Ifigênia. 


\section{Os procedimentos de criação}

Descrevo abaixo, brevemente, alguns dos procedimentos de criação utilizados no processo de ensaios?.

Em seus experimentos práticos de articulação entre o trágico e o Campo de Visão, a Cia Elevador trabalhou amplamente alguns elementos constituintes de seu sistema de criação (alguns deles descritos anteriormente de forma breve) como motivadores do jogo:

- o tema da tragédia;

- a relação coro-protagonista;

- a relação movimento-pausa;

- a criação dos personagens, de onde descobriram e compuseram o que chamaram de "Gestoteca": os atores experimentavam-se nos diversos personagens enquanto eram líderes do jogo e os movimentos que se mostravam mais significativos eram selecionados com a ajuda do diretor/condutor. Este processo de apropriação de repertório alheio para a criação de um repertório coletivo gerou uma gestualidade que serviria a cada personagem quando, durante o espetáculo, os atores entrassem em jogo construindo a encenação.

Com a chegada do texto final, todos os atores ${ }^{10}$ decoraram-no por inteiro e, além de continuarem trabalhando os elementos citados acima, partiram para a investigação de alguns princípios concernentes, especificamente, àquela dramaturgia, como:

- diferentes dimensões do narrador;

- a dinâmica de intensidade e tensão exigida pela fábula;

Além dos atores, os músicos e o operador de luz acompanharam todo o processo de criação e também improvisariam durante as apresentações, jogando com a movimentação proposta pelos atores. Boa parte da trilha sonora da peça seria executada ao vivo mas, vale ressaltar, que alguns momentos musicais eram gravados e previamente demarcados. Bem como o operador de luz jogaria com os atores, mas alguns desenhos de iluminação foram preestabelecidos.

Das poucas marcas previamente estabelecidas, a maioria relacionava-se diretamente aos intervalos entre as cenas, aos momentos de Ponto Zero. O U rigoroso do Ponto Zero do Campo de Visão tradicional foi transformado em novas estruturas. Para cada Ponto Zero proposto pelo dramaturgo foi criado um desenho específico no espaço que se

\footnotetext{
9 Tive acesso a estes procedimentos por meio de entrevistas realizadas com o diretor e o dramaturgo da peça. A entrevista realizada com Marcelo Lazzaratto foi em dezembro de 2012.

10 Elenco original de Ifigênia: Carolina Fabri, Daniela Alves, Gabriel Miziara, Manfrini Fabretti, Maurício Schneider, Pedro Haddad, Rodrigo Spina, Sofia Botelho e Wallyson Mota.
} 
repetiria rigorosamente em cada apresentação. Ficou definido, também, que a fala do Mar no Ponto Zero seria sempre coral, por vezes cantada. Estes momentos de Ponto Zero, a movimentação inicial dos atores e a primeira fala da peça foram as únicas marcas rígidas estabelecidas a priori. A partir daí todo o resto seria improvisado.

Com estas definições, o processo de ensaios passou a ser jogar o espetáculo dentro da estrutura preparada para que ele acontecesse nas apresentações com o público.

\section{A experiência da cena}

Postos todos os aspectos acima, para falar da experiência da cena levada ao público, me restam mais impressões e perguntas do que propriamente análises, críticas ou descrições.

O que pude ver nas apresentações foi o resultado - que ousaria dizer, quase empiricamente comprovável - de doze anos de pesquisa de linguagem e desenvolvimento de treinamento do artista da cena, um trabalho sério e incansável sobre o Campo de Visão aliado a muitos meses de mergulho no universo da tragédia e na articulação entre estas matérias.

A experiência de Ifigênia se dá no cruzamento de diferentes dimensões: o espetáculo acontece enquanto jogo, enquanto composição e enquanto ritual. Os limites destas dimensões são esfumaçados: elas por vezes alternam-se, por vezes contaminam-se e por vezes são simultâneas. Todas elas, no entanto, provocam uma qualidade de atitude nos atores que interessa e seduz o espectador desde os primeiros instantes.

Vemos em cena nove atores-jogadores com profundo conhecimento e compreensão da história que estão contando. Corajosos, deixam os personagens surgirem em cada um deles e ao espectador cabe jogar este jogo e deleitar-se ao descobrir que a Onda/Clitemnestra naquela noite deverá ser mais de uma (ou um) - como também serão várias as Ondas/Agamêmnon, Ifigênia, Menelau - e perceber que ele será capaz de acompanhar e se relacionar com a história. Se no começo o espectador corre o risco de se dispersar da narrativa pela contundência e força do jogo e da movimentação dos atores e teme ter perdido algum detalhe, percebe logo que isso não se configura como um problema, pois o dramaturgo esteve atento e retomará as informações importantes adiante no texto e, além disso, os atores tem a habilidade de contar a história com muita clareza e propriedade, sem perder a intensidade.

É impactante perceber que os atores estão compondo naquela hora a encenação, desenhando no espaço e produzindo sentido através do jogo vivo entre eles. Eles estão em 
constante estado de alerta, o que traz uma vibração poderosa para o espetáculo. O estado de tensão proposto pelas circunstâncias do texto é preservado durante toda a apresentação. O mérito - como não poderia deixar de ser, já que é resultado do trabalho deste grupo de artistas que em sua própria história redimensiona a importância da coletividade - está no conjunto. Não interessa buscar, descobrir ou perceber se existem atores "melhores" que outros. No entanto, este é também um ponto sensível: a força do jogo coletivo pode ser cruel, pois denuncia qualquer fragilidade dos atores: percebemos imediatamente quando algum deles, por um instante que seja, desconecta-se, omite-se, deixa de escutar ou se impõe excessivamente.

É certo que a experiência é bem diversa para quem sabe que a peça é improvisada e para quem não tem esta informação (conheço pessoas que saíram do espetáculo sem descobrir isto!). Ou ainda, para quem conhece e quem não conhece o Campo de Visão. Pergunto-me qual o impacto destas diferenças e, obviamente, incapaz de encontrar uma resposta, arrisco-me em dois palpites: por um lado, se em alguma apresentação o jogo não se der plenamente, se a vida escapar da relação dos atores com o instante, a experiência pode deixar de ser interessante e parecer mero exercício formal/de estilo; por outro lado, sempre que a peça acontece integralmente, sua dimensão ritual dá, a quem não percebe que o espetáculo está sendo construído no momento, o privilégio do invisível, que é onde mora o sagrado (BROOK, 1970).

O espetáculo Ifigênia é bem mais que um jogo bem jogado, é um devir, não um ser. Devir - conceito amplamente desenvolvido por diversos pensadores, é aqui entendido pelo ponto de vista do filósofo Luiz Fuganti ${ }^{11}$ - como o estado do que é vivo, uma variação contínua, o que a potência do homem torna-se ininterruptamente no fluxo da vida. Devir como o estofo mesmo do real, o que sustenta e gera a própria vida - vida entendida como criação de realidade. Devir como o que as forças tornam-se ao efetuarem-se, a modificação que as potências da natureza e da realidade sofrem ao efetuarem-se. Devir como tornar-se diferente de si mesmo à medida que vai existindo.

Ora, segundo esta tese, todo espetáculo teatral deveria ser um devir. Mas, assim como nós, que vivemos neste tempo cada vez mais separados do devir e chafurdados no ser, nossa arte, nosso teatro também padece desta consciência/existência equivocada. Em Ifigênia, a potência do existir entendido como devir, não como ser, é amplificada pelo fato

\footnotetext{
11 As ideias de Luiz Fuganti aqui apresentadas foram extraídas da palestra Teatro e Acontecimento, proferida por ele em 05/11/2012 na abertura do II Seminário de Pesquisas em Andamento do Programa de PósGraduação em Artes Cênicas da ECA/USP. Disponível em http://vimeo.com/53109221\#at=0.
} 
de que a peça tem, entre suas premissas fundamentais, o compromisso de se reinventar a cada apresentação, a partir do acontecimento real de cada instante.

Ainda segundo Fuganti, nós não somos culpados, mas somos cúmplices do que nos acontece e, sobretudo, do que fazemos com o que nos acontece. Mesmo os que chafurdam e paralisam na ideia de ser estão sempre no devir. Como no Campo de Visão, o sujeito está sempre em acontecimento. No devir inevitável. Mas há os que moram no devir reativo. Eles dependem de um ato exterior que os modifiquem. E não se responsabilizam pelo que julgam ser. E mínguam a potência da sua potência, a potência da sua vida, pois o meu devir, o que minha potência se torna, depende da maneira como eu existo. Maneira aqui entendida como uma composição entre mim e o fora, mas sabendo que há na maneira algo que só depende de mim e aí entra minha responsabilidade ética com minha própria existência.

Mas, se no espetáculo Ifigênia, o ator leva em consideração o outro ${ }^{12}$, a ponto de ser definido por ele (LAZZARATTTO, 2011), ser guiado por ele, ser movido por ele, temos ali um devir reativo? Não. Não porque a força do devir ativo é aumentada pelo princípio da alteridade, que existe na peça em sua plenitude. $\mathrm{O}$ ator renova a intensidade de sua própria experiência através do outro, pela capacidade de se relacionar e se deixar afetar pelo outro, pelo mundo, pelo que é externo ao indivíduo. Assim, cria recriando e co-criando sua realidade, a partir desta afecção. A composição entre o mim e o fora é, assim, outra premissa fundamental desta obra, mas aqui o sujeito não se acomoda numa relação de dependência e reatividade ao externo que é o outro, ao contrário, quanto mais está no acontecimento, mais está com outro. Ele se coloca em estado de receptividade, de afecção e de responsabilidade, gerando em si e no todo um devir ativo, pulsante, um devir criativo. Ele é agente, define o seu entorno e, simultaneamente, está inserido em algo que o define, é agido.

O Ifigênia - alicerçado no Campo de Visão, uma técnica-poética que cria espaço para experimentação ética e filosófica com o corpo, interessada mais em criação de subjetividades que em novos resultados - carrega fortemente uma proposição poética de enfrentamento ético quando coloca uma lupa na questão da alteridade e do coletivo neste tempo em que vivemos sob o imperativo do "faça-se a si mesmo" da cultura burguesa e da indolência dos devires reativos, que tudo julgam e nada criam.

\footnotetext{
12 Outro entendido, pelo próprio Lazzaratto, como qualquer elemento que não constitua o ator em uma primeira instância, por exemplo, um outro ator, uma música, um objeto, um texto, um personagem.
} 
Por fim, tomo a palavra "Visão" no contexto do Campo de Visão e proponho ultrapassar seu sentido imediato e chegar à palavra Visionário, proposta por Jung, como aquele artista que rasga a cortina cósmica, cuja obra produz sentidos alcançados apenas nas profundezas, e que acaba por dizer bem mais do que percebe que está dizendo (JUNG, 2011). Reconheço os artistas do Ifigênia - diretor, atores-jogadores, dramaturgo e toda a equipe que foi capaz de dialogar com as inquietações da Cia Elevador -, estes corpos que se conectaram e deram seu depoimento pleno de potência abertos para o outro e afetados por ele, como visionários. Os poetas do Ifigênia, os poetas do Campo de Visão são visionários. Eles não fazem esta peça, ela se faz através da pulsão de todos eles em conexão. A obra é maior que eles, por isso ela é grande e os torna, cada um deles, também grandes.

\section{REFERÊNCIAS BIBLIOGRÁFICAS:}

BROOK, Peter. O teatro e sen espaço. São Paulo, Vozes, 1970.

CORVIN, Michel. Dictionnaire encyclopédique du théatre. Québec, Larousse, 1998.

FOUCAULT, Michel. Le corps utopique. Les hétérotopies. Paris, Nouvelles Editions Lignes, 2009.

EURÍPIDES. Ifigênia em Aulis, As Fenícias, As Bacantes. Tradução: Mario da Gama Kury. Rio de Janeiro, Zahar, 2005.

JUNG, Carl Gustav. O espirito na arte e na ciência. São Paulo, Vozes, 1996.

LAZZARATTO, Marcelo. Campo de Visão: exercício e linguagem cênica. São Paulo, Escola Superior de Artes Célia Helena, 2011.

. Ifigênia: o mar e suas ondas. In: Ifigênia: programa do espetáculo. São Paulo, SESCSP, 2012.

PIRES, Cássio. Ifigênia. In: Sobe? Ano II, n. 2. São Paulo, 2012a.

SESCSP, 2012b.

Os autores de Ifigênia e os corpos coletivos. In: Ifigênia: programa do espetáculo. São Paulo,

TOSCANO, Antônio Rogério. Agreste: uma dramaturgia desejante. In: Sala Preta. n. 4. São Paulo, ECA/USP, 2004.

Abstract: This paper analyzes the play Iphigenia, produced by Cia. Elevador de Teatro Panorâmico. The play, written by the contemporary playwright Cássio Pires, was inspired in Euripides' Iphigenia in Aulis. The play was directed by Marcelo Lazzaratto, who developed the fundamental construction procedure of the mise-èn-scene: the improvisational system "Field of Vision", the central theme of this analysis.

Keywords: tragedy; improvisation; Field of Vision. 